UDC: 615.12:615.012(669.1)

DOI: $10.15587 / 2313-8416.2016 .62439$

\title{
CONTEMPORARY CHALLENGES OF PHARMACEUTICAL COMPOUNDING IN SOUTHERN NIGERIA: RESULTS OF SURVEY
}

\author{
(C) D. Alfred-Ugbenbo, O. Zdoryk, V. Georgiyants
}

In the past decade the pharmacy practice worldwide has witness a trend shift from product-orientation to patient-orientation. This and other reasons encouraged the Nigerian government and its institutions to systematically de-emphasized through its budget, funding for the development of compounding unit.

Aim: The aim of given article was to examine the challenges facing compounding pharmacists in hospital pharmacies, cost estimating of extemporaneous preparations and searching of solutions.

Methods: A closed and open-ended format questionnaire was distributed to 50 compounding pharmacists in Rivers State of Nigeria. The questionnaire comprised of a cover letter and 10 items which cut across personnel training, staffing, premise and equipment, logistics, cost of compounding, national reference standards on compounding, in-pharmacy control.

Results: From the survey results, challenges of compounding pharmacies in southern Nigeria such as inadequate manpower, absence of electronic documentation, facilities and funding; lack of national formulary on extemporaneous formulations and locally conducted stability tests were revealed. Cost of extemporaneous preparations ranged from 1-15 US dollars.

Conclusions: Development and implementation of easily accessible national formulary on extemporaneous formulations and their stability study, development of standard operating procedures for all activities in the pharmacy and staff training on recent technologies in compounding preparations are recommended

Keywords: compounded preparations, hospital pharmacy, questionnaire, standard operating procedure, national formulary, stability

За останне десятиліття в фармаџевтичній практищі в усьому світі спостерігається тенденція переходу від продуктової орієнтаиії на орієнтацію на паџієнта. Через дану та інші причини уряд Нігерії та його інституиії систематично скорочують бюджетні кочти на розвиток блоку аптечного виготовлення.

Метою даної статті було визначення проблем, що постають перед фармачевтичними працівниками госпітальних аптек, оцінка вартості екстемпоральних лікарських засобів та пошук рішень.

Матеріали і методи: Анкета, щчо включала в себе закриті і відкриті питання, була поширена серед 50 фармацевтів виробничих аптек в штаті Ріверс, Нігерія. Анкета складалася з пояснювальної записки і 10 питань, які стосувалися навчання персоналу, кадрового забезпечення, приміщення та обладнання, логістики, вартості виготовлення, начіональних стандартів виготовлення, внутрішньоаптечного контролю якості.

Результати: Виходячи з результатів анкетування, проблемами виробничих аптек у південній Нігерії $є$ неналежна кількість персоналу, відсутність електронного документування, обладнання і фінансування; було виявлено відсутність національного формуляру екстемпоральних лікарських засобів та проведених досліджень на стабільність. Вартість екстемпоральних лікарських засобів коливається в межах від 1 15 доларів США.

Висновки: Рекомендуються розробка та впровадження легко доступного національного формуляру на екстемпоральні лікарські засоби і їх вивчення стабільності, розробка стандартних операчійних процедур для всіх видів діяльності в аптеці і підвищення кваліфікації персоналу про новітні технології виготовлення лікарських засобів в аптеках

Ключові слова: лікарські засоби аптечного виготовлення, госпітальна аптека, анкета, стандартна операційна процедура, національний формуляр, стабільність

\section{Introduction}

In the past decade the pharmacy practice worldwide has experienced a shift from product-orientation to patient-orientation [1-3]. Compounding is the preparation (mixing, altering, assembling), under the supervision of a licenced pharmacist, of a medication that is not commercially available in the concentration or form needed for a specific patient pursuant to a prescription [4]. Products of compounding are called compounded preparations, extemporaneous formulations and compounded medications. The British pharmacopoeia refers to them as unlicensed medicines [5].
2. Formulation of the problem in a general way, the relevance of the theme and its connection with important scientific and practical issues

At the present stage of development of pharmaceutical industry there is a need to preserve the compounding of medicines in pharmacies. The Nigerian government and its institutions also have over the years, systematically deemphasized through its budget, funding for the compounding unit. Today the compounding of medicines usually involves a small number of state and hospital pharmacies. In this regard, the majority of the population is limited acquisition opportunities in extemporaneous preparations. 


\section{Analysis of recent studies and publications in} which a solution of the problem and which draws on the author

Organizational and economic problems of pharmaceutical compounding and its preservation for a long time are discussed by the pharmaceutical community [6-9]. Usually these problems are due to insufficient development of the pharmaceutical legislation in the absence of adequate funding.

4. Allocation of unsolved parts of the general problem, which is dedicated to the article

Study of problems of pharmaceutical compounding and dynamics of main economic indicators are relevant today. These include compliance to good compounding and pharmacy practices such as standard operating procedures, accessible harmonized national formulary and updates on local stability tests for extemporaneous formulations, quality control, and cost of extemporaneous preparations, logistics and adequate facilities.

\section{Formulation of goals (tasks) of article}

The aim of this study is to examine challenges facing compounding pharmacists in hospital pharmacies in southern Nigeria, cost of extemporaneous preparations and proffer solutions.

6. Statement of the basic material of the study (methods and objects) with the justification of the results

A closed and open-ended format questionnaire was distributed to 50 compounding pharmacists. The survey was conducted in River State (southern Nigeria) within the period of October - December 2015. The questionnaire comprised of a cover letter and 10 items which cut across personnel training, staffing, premise and equipment, logistics, cost of compounding, national reference standards on compounding, in-pharmacy control. The statement was considered accepted if it is affirmed by $50 \%$ of the respondents. Data from questionnaire were analysed into Microsoft Excel 2010 and summarized below.

Out of the 50 distributed questionnaires, a total of 48 were returned, representing a $96 \%$ response rate of the sample size. Mean scores were determined for each item and the summarized data presented below.

Table 1

Relevant responses from administered questionnaire

\begin{tabular}{|c|c|c|c|c|c|c|c|}
\hline$\#$ & \multirow{3}{*}{$\begin{array}{c}\text { Questions } \\
\text { Do you believe a biennial } \\
\text { seminar/workshop for com- } \\
\text { pounding pharmacists on re- } \\
\text { cent scientific research is } \\
\text { necessary? }\end{array}$} & \multicolumn{6}{|c|}{ Scales (responses) } \\
\hline \multirow{2}{*}{1} & & \multicolumn{2}{|c|}{ Yes } & & \multicolumn{3}{|c|}{ No } \\
\hline & & \multicolumn{2}{|c|}{$100 \%$} & \multicolumn{4}{|c|}{$0 \%$} \\
\hline \multirow[t]{2}{*}{2} & \multirow{2}{*}{$\begin{array}{l}\text { Type of API used during } \\
\text { compounding }\end{array}$} & \multicolumn{2}{|c|}{ Pure } & \multicolumn{4}{|c|}{$\begin{array}{l}\text { API, as part of commercial drug } \\
\text { (tablet, capsule, injection etc) }\end{array}$} \\
\hline & & \multicolumn{2}{|c|}{$7.1 \%$} & \multicolumn{4}{|c|}{$92.9 \%$} \\
\hline \multirow[t]{2}{*}{3} & \multirow[t]{2}{*}{ Vehicles/bases used } & $\begin{array}{l}\text { Import- } \\
\text { ed(ORA-Plus, } \\
\text { ORA- } \\
\text { Sweet etc) }\end{array}$ & $\begin{array}{l}\text { Locally avail- } \\
\text { able (Vit C, } \\
\text { Vit BCo etc) }\end{array}$ & \multicolumn{2}{|c|}{ Both } & \multicolumn{2}{|c|}{$\begin{array}{c}\text { Abstained from answering } \\
\text { question }\end{array}$} \\
\hline & & $47.6 \%$ & $38.1 \%$ & \multicolumn{2}{|c|}{$11.9 \%$} & \multicolumn{2}{|c|}{$2.4 \%$} \\
\hline \multirow[t]{2}{*}{4} & \multirow{2}{*}{$\begin{array}{l}\text { What determines the cost of a } \\
\qquad R_{x}\end{array}$} & API & Base/Vehicle & \multicolumn{2}{|c|}{ Both } & \multicolumn{2}{|c|}{$\begin{array}{c}\text { Abstained from answering } \\
\text { question }\end{array}$} \\
\hline & & $16.7 \%$ & $23.8 \%$ & \multicolumn{2}{|c|}{$52.4 \%$} & \multicolumn{2}{|c|}{$7.1 \%$} \\
\hline \multirow[t]{2}{*}{5} & \multirow[t]{2}{*}{$\begin{array}{l}\text { Possible high cost for a com- } \\
\text { pounded preparation }(\$)\end{array}$} & 1 USD & $1-3$ USD & 3-5 USD & 5-15 USD & $>15$ USD & $\begin{array}{l}\text { Abstained } \\
\text { from } \\
\text { answering } \\
\text { question }\end{array}$ \\
\hline & & $2.4 \%$ & $16.7 \%$ & $61.9 \%$ & $4.8 \%$ & $7.1 \%$ & $7.1 \%$ \\
\hline \multirow[t]{2}{*}{6} & \multirow{2}{*}{$\begin{array}{l}\text { Possible low cost for a com- } \\
\text { pounded preparation }(\$)\end{array}$} & $<0.5$ USD & $<1 \mathrm{USD}$ & 1-3 USD & 3-5 USD & \multicolumn{2}{|c|}{$\begin{array}{c}\text { Abstained from answering } \\
\text { question }\end{array}$} \\
\hline & & $9.6 \%$ & $14.3 \%$ & $61.9 \%$ & $7.1 \%$ & & \\
\hline \multirow[t]{2}{*}{7} & \multirow{2}{*}{$\begin{array}{l}\text { Awareness/existence of Nig. } \\
\text { Ref. standards on compound- } \\
\text { ing or quality control }\end{array}$} & \multicolumn{2}{|c|}{ Aware } & \multicolumn{2}{|c|}{ Not aware } & \multicolumn{2}{|c|}{$\begin{array}{l}\text { Abstained from answering } \\
\text { question }\end{array}$} \\
\hline & & & & & & & \\
\hline 8 & $\begin{array}{l}\text { Existence/awareness of stabil- } \\
\text { ity tests conducted in/for the }\end{array}$ & & & No & are & $\begin{array}{r}\text { Abstained } 1 \\
q u\end{array}$ & $\begin{array}{l}m \text { answering } \\
\text { tion }\end{array}$ \\
\hline & country & & & & & & \\
\hline 9 & Adequacy of quality control & $\mathrm{Ad}$ & Iate & Ina & date & $\begin{array}{r}\text { Abstained } \\
\text { qu }\end{array}$ & $\begin{array}{l}\mathrm{m} \text { answering } \\
\text { tion }\end{array}$ \\
\hline & & & & & & & $\%$ \\
\hline 10 & Who should equip the Q.C. & Hospital & Government & $\begin{array}{l}\text { Private } \\
\text { firms }\end{array}$ & $\mathrm{H}+\mathrm{G}$ & All sta & holders \\
\hline & & $33.3 \%$ & $42.9 \%$ & - & $11.9 \%$ & & $\%$ \\
\hline
\end{tabular}


Cost: Compounding in Nigeria is done mainly in government-owned hospital pharmacies, where the cost of extemporaneous preparations is highly subsidized. Whilst $61.9 \%$ of respondents pegged the possible high cost of a compounded prescription to be in the range of 3-5 USD, extemporaneous formulations in the pharmacy could go for as high as 15 USD. $61.9 \%$ of respondents pegged the lowest possible cost of a compounded prescription to be in the range of 3-5 USD. $52.4 \%$ of respondents agree that the cost of both APIs and vehicles/bases determine the final cost of the extemporaneous medication. The cost of APIs is subsidized if they are included in the National health insurance scheme (NHIS) drug list [10]. A fee (maybe fixed) for compounding service as proposed and obtainable in some countries should be stipulated to enable the pharmacist place the patient as the primary focus and the cost of the product as a secondary in priority [11].

Personnel and training: $100.0 \%$ of the respondents approved a biennial seminar/workshop on recent scientific development on compounding; the curriculum should include the course of quality assurance of compounding preparations [12].

Staffing: The ratio of compounding pharmacists to population is very low [13]. This poses a threat of wearout, prescription errors and less time devoted to patient counselling on medications. Compounding is done mainly by pharmacists.

Documentation: Thanks to routine preparation of monthly reports the practice of documentation has being strong. However, only $30.9 \%$ of respondents had switched to electronic (computer-based) documentation of compounded formulations. Their reasons bothered on time constraint as a result of understaffing.

Logistics: availability of required APIs and excipients (vehicle/bases) is an important aspect of compounding. Although use of pure substances is preferable, $92.9 \%$ use commercial drugs (tablet, capsules etc.) as APIs for compounding. Vehicles/bases utilised include ORA-Plus, ORA-Sweet, cherry syrup, simple syrup USP. A staggering $50 \%$ of the respondents said there was difficulty accessing required ingredients for compounding. The problem of logistics is being tackled by both the Nigerian government and the Pharmaceutical Society of Nigeria through a proposed Mega drug distribution System $[14,15]$.

Premises and equipment: Until recently, the pharmacy unit as a whole was planned and designed by doctors. Pharmacists made no input. As a result compounding units are poorly planned. Head of Hospitals and clinics (doctors) are forced to make readjustments of the pharmacy premises to meet a required specification recommended by the NHIS [16], when they apply for accreditation to join the scheme. Since compounding units is not a compulsory requirement for registration of hospital pharmacies with the scheme, pharmacists are forced to make a strong case for its inclusion. Compounding unit specifications should be stipulated and included in the requirements for setup of a hospital.
Quality Control: $76.2 \%$ complain of inadequately equipped compounding units. $33.3 \%$ and $42.9 \%$ ascribe responsibility of an adequately equipped compounding unit on the hospital itself and government respectively. $11.9 \%$ place the responsibility on both while the same percentage believes all (including private firms) stakeholders share the responsibility. All respondents (100\%) acceded to the need for development and implementation of standard operating procedures (SOP) for all activities in the pharmacy, including all stages of compounding, routine cleaning procedures, compounding equipment and environmental conditions under which products are prepared to enhance quality assurance [17].

In-pharmacy control: $100 \%$ of the participants (respondents) confirmed in-pharmacy control. Prescriptions are vetted before compounding. Calculations and technology of production are checked by the supervising pharmacist before compounding. The compounded formulation is checked by another pharmacist before dispensing. Stocks are checked monthly. Erring pharmacists are retrained on the job. Raw materials are examined on reception, before storage and before use. Inspection of compounding by regulatory bodies is less frequent.

Reference standard: the reference standards used within the pharmacy include the British Pharmaceutical Codex, British Pharmacopoeia, United States Pharmacopoeia, the American Society of Health System Pharmacists Drug Information, Information from the International Journal of Pharmaceutical Compounding and other available sources that provide information on stability studies or recent updates relating to drug compounding. From the survey, $95.2 \%$ of respondents are not aware of the existence of a national reference standard. Neither is $61.9 \%$ aware of any stability tests being conducted in/for the country (Nigeria). A template for national formulary for compounded drugs is therefore proposed in Fig. 1, similar to existing/proposed formats in other countries [18-20].

This should be in a database form, containing readily accessible formulary to pharmacists nationwide. The formulary should include formula magistrals and medicines prepared by a hospital or community pharmacy in accordance with instructions in a compendium, pharmacopoeia or a formulary and dispensed by a pharmacy to patients $[21,22]$.

It should be subject to regular updates and a channel (or forum) [23] be created for inputs on new formulas/recipe. The advantages include access to locally usable information, increased quality assurance, inputs from academic and practicing pharmacists, and a harmonised national formulary of suitable formulations [24]. Stability tests should be made using products readily available in the country. Since generics of the same drug may produce different stability results due to the use of different excipients, it becomes necessary that the specific company producing the generic be mentioned. 


\section{Formulation Record}

Name/Strength/Dosage form: Propranolol $1 \mathrm{mg} / \mathrm{ml}$ Suspension

Route of Administration: Oral

\begin{tabular}{|l|c|c|}
\hline \multicolumn{1}{|c|}{ Ingredients } & Strength & Quantity \\
\hline Propranolol Tablets & $40 \mathrm{mg}$ & 6 tablets \\
\hline $\begin{array}{l}\text { Distilled water(wetting } \\
\text { agent) }\end{array}$ & & $4.8 \mathrm{ml}$ \\
\hline Citric acid Solution & $25 \%$ & $1 \mathrm{ml}$ \\
\hline Simple Syrup & qs & $240 \mathrm{ml}$ \\
\hline
\end{tabular}

\section{Procedure:}

1. Crush tablets in a mortar to a fine powder.

2. Levigate the powder with distilled water until a smooth paste.

3. Add a small amount of simple syrup to form a smooth paste. Add more syrup until a liquid is formed and transfer the contents into a graduated cylinder. Use additional simple syrup to rinse the remaining drug from the mortar.

4. Add citric acid to the suspension in the graduate. Mix well.

5. QS to final volume with simple syrup.

6. Transfer the suspension into amber bottle

7. Shake well and label

Storage requirements: Refrigerate. Keep in amber bottle. Protect from light. Stability: $\mathbf{4 5}$ days

\section{Reference:}

1. Pharmacy Compounding Manual May 2011, Alberta Health Services Calgary and Area ,p. 179

2. Milap C. Nahata, Vinita B.Pai, Thomas F.Hipple. Peadiatric Drug Formulation, 5th Edition, 2004 p. 233.

Fig. 1. Proposed format for compounding preparation formulary

\section{Conclusion}

The survey reveals challenges of compounding pharmacists in southern Nigeria such as inadequate manpower, electronic documentation, facilities and funding, access to a comprehensive national formulary on extemporaneous formulations and locally conducted stability tests.

Full electronic documentation, increased government funding for quality assurance conditions, logistics, adequate equipment of the compounding and quality control units, recruitment of more pharmacists is advocated.

An easily accessible national formulary on extemporaneous formulations and their stability study, development and implementation of SOP for all activities in the pharmacy and staff training on recent technologies in compounding preparation are recommended.

\section{References}

1. Martin, S. Hospital Pharmacy [Text] / S. Martin. 2-nd ed. - UK: Pharmaceutical Press, 2011. - P. 140-141.
2. Karin, W. Developing pharmacy practice - a focus on patient care [Text] / W. Karin, R. S. Summers, C. A. Mackie, A. G. S. Gous, M. Everard // World Health Organization and International Pharmaceutical Federation. - 2006. - P. 9-12.

3. Okhamafe, A. O. A review of B.Pharm degree pharmaceutics and pharmaceutical technology curriculum component [Text]: conference / A. O. Okhamafe; P. I. Akubue, B. A. Fred (Eds.). - Nigeria, 2001. - P. 56-63.

4. Pharmaceutical Compounding - Nonsterile Preparations <795> [Text]. - Revision bulletin. - 2014. - P. 1-7. Available at: http://www.usp.org/sites/default/files/usp_pdf/EN/ gc795.pdf

5. General notices part II- Unlicensed medicines. British Pharmacopoeia [Text]. - 7-th ed. - London: The Stationary Office, 2013.

6. Managing Access to Medicines and Health Technologies [Text] / E. Martha, R. Marian (Eds.). - 3-rd ed. - Arlington, VA: Management Sciences for Health, 2012. - P. 29-178.

7. Aldo, M. Compounding in Argentina [Text] / M. Aldo // International Journal of Pharmaceutical Compounding. 2008. - Vol. 12, Issue 2. - P. 104. 
8. Marisol, L. Compounding in Puerto Rico [Text] / L. Marisol // International Journal of Pharmaceutical Compounding. - 2008. - Vol. 12, Issue 2. - P. 110-111.

9. Diego, M. Compounding in Spain [Text] / M. Diego // International Journal of Pharmaceutical Compounding. 2008. - Vol. 12, Issue 2. - P. 112-113.

10. Drug price list [Text]. - 2-nd ed. - National Health Insurance Scheme. - Abuja, 2013. - P. 2-32.

11. Fink, J. F. Student Sketches [Text] / J. F. Fink // Journal of the American Pharmaceutical Association (1961). - 1969. Vol. 9, Issue 3. - P. 140. doi: 10.1016/s0003-0465(15)31817-6

12. Zdoryk, O. A. Organization of the quality assurance system of compounding pharmacies in Ukraine: results of the survey [Text] / O. A. Zdoryk // News of Pharmacy. - 2014. Vol. 4, Issue 80. - P. 64-67.

13. FIP Global Pharmacy Workforce Report [Electronic resource]. - 2012. - Available at: http://www.fip.org/files/ members/library/FIP_workforce_Report_2012.pdf

14. Ojo, L. A closer look at the new national drug distribution guidelines [Text] / L. Ojo // Pharmanews. - 2014. Available at: http://www.pharmanewsonline.com/a-closer-lookat-the-new-national-drug-distribution-guidelines/

15. Nigerian government to enforce drug distribution guidelines from July 1 [Electronic resource]. - Health news. 2015. - Available at: http://healthnewsng.com/nigerian-government-to-enforce-drug-distribution-guidelines-from-july-1/

16. Operational guidelines [Text]. - National Health Insurance Scheme. - Abuja, 2012. - P. 58-60.

17. Kastango, E. S. Quality assurance for sterile products [Text] / E. S. Kastango, K. Douglass // Int. J. Pharm. Compd. - 2001. - Vol. 5, Issue 4. - P. 246-253.

18. Pharmacy Compounding Manual [Text]. - Calgary Health Region Pharmacy. - 2008. - P. 204.

19. Pharmaceutical Division Service [Text]. - Ministry of Health Extemporaneous formulary. - Malaysia, 2011. P. 1-57.

20. Evans, A. Development of a standardized intranet database of formulation records for nonsterile compounding, part 1 [Text] / A. Evans, M. Haile, K. Anderson // Int. J. Pharm. Compd. - 2010. - Vol. 14, Issue 5. - P. 401-405.

21. Ministério da Saúde. Decreto-Lei n. ${ }^{\circ}$ 95/2004, de 22 de Abril, Artigo $1^{\circ}$ [Text] // Diário da República. - 2004. I Série-A 95. - P. 2440.

22. CETMED. Formulário Galénico Português [Text]. 2-nd ed. - Lisboa: Associação Nacional das Farmácias, 2005.

23. European cooperation and synergy in quality standards beyond the European pharmacopoeia [Text]. - National experiences of formularies. - EDQM Symposium Strasbourg, France, 2007.

24. Expert Advisory Group ULM 14 [Text]. - British Pharmacopoeia Commission: Unlicensed Medicines. - London, 2014. - Available at: https://www.pharmacopoeia. com/file/ ULM---November-2014.pdf

\section{References}

1. Martin, S. (2011). Hospital Pharmacy. UK: Pharmaceutical Press, 140-141.

2. Karin, W., Summers, R. S., Mackie, C. A., Gous, A. G. S., Everard, M. (2006). Developing pharmacy practice - a focus on patient care. World Health Organization and International Pharmaceutical Federation, 9-12.

3. Okhamafe, A. O.; Akubue, P. I., Fred, B. A. (Eds.) (2001). A review of B.Pharm degree pharmaceutics and pharmaceutical technology curriculum component. Nigeria, 56-63.

4. Pharmaceutical Compounding - Nonsterile Preparations $\langle 795\rangle$ (2014). - Revision bulletin, 1-7. Available at: http://www.usp.org/sites/default/files/usp_pdf/EN/gc795.pdf 5. General notices part II- Unlicensed medicines. British Pharmacopoeia (2013). London: The Stationary Office.

6. Martha, E., Marian, R. (Eds.) (2012). Managing Access to Medicines and Health Technologies. Arlington, VA: Management Sciences for Health, 29-178.

7. Aldo, M. (2008). Compounding in Argentina. International Journal of Pharmaceutical Compounding, 12 (2), 104.

8. Marisol, L. (2008). Compounding in Puerto Rico. International Journal of Pharmaceutical Compounding, 12 (2), 110-111.

9. Diego, M. (2008). Compounding in Spain. International Journal of Pharmaceutical Compounding, 12 (2), $112-113$.

10. Drug price list (2013). National Health Insurance Scheme. Abuja, 2-32.

11. Fink, J. F. (1969). Student Sketches. Journal of the American Pharmaceutical Association (1961), 9 (3), 140. doi: 10.1016/s0003-0465(15)31817-6

12. Zdoryk, O. A. (2014). Organization of the quality assurance system of compounding pharmacies in Ukraine: results of the survey. News of Pharmacy, 4 (80), 64-67.

13. FIP Global Pharmacy Workforce Report (2012). Available at: http://www.fip.org/files/members/library/FIP workforce_Report_2012.pdf

14. Ojo, L. (2014). A closer look at the new national drug distribution guidelines. Pharmanews. Available at: http:// www.pharmanewsonline.com/a-closer-look-at-the-new-nationaldrug-distribution-guidelines/

15. Nigerian government to enforce drug distribution guidelines from July 1 (2015). Health news. Available at: http://healthnewsng.com/nigerian-government-to-enforce-drugdistribution-guidelines-from-july-1/

16. Operational guidelines (2012). National Health Insurance Scheme. Abuja, 58-60.

17. Kastango, E. S., Douglass, K. (2001). Quality assurance for sterile products. Int. J. Pharm. Compd., 5 (4), 246-253.

18. Pharmacy Compounding Manual (2008). Calgary Health Region Pharmacy, 204.

19. Pharmaceutical Division Service (2011). Ministry of Health Extemporaneous formulary. Malaysia, 1-57.

20. Evans, A., Haile, M., Anderson, K. (2010). Development of a standardized intranet database of formulation records for nonsterile compounding, part 1. Int. J. Pharm. Compd., 14 (5), 401-405.

21. Ministério da Saúde. Decreto-Lei n. ${ }^{\circ}$ 95/2004, de 22 de Abril, Artigo $1^{\circ}$ (2004). Diário da República, I Série-A $95,2440$.

22. CETMED. Formulário Galénico Português (2005). Lisboa: Associação Nacional das Farmácias.

23. European cooperation and synergy in quality standards beyond the European pharmacopoeia (2007). National experiences of formularies. EDQM Symposium Strasbourg, France.

24. Expert Advisory Group ULM 14 (2014). British Pharmacopoeia Commission: Unlicensed Medicines. London. Available at: https://www.pharmacopoeia.com/file/ULM--November-2014.pdf

Deghinmotei Alfred-Ugbenbo, Postgraduate student, Department of Pharmaceutical chemistry, National University of Pharmacy, Pushkinska str., 53, Kharkiv, Ukraine, 61002

E-mail: audeghinmotei@gmail.com 
Zdoryk Oleksandr, Candidate of pharmaceutical science, Associate professor, Pharmaceutical chemistry department, National University of Pharmacy, Pushkinska str., 53, Kharkiv, Ukraine, 61002

E-mail: oleksandr_zdoryk@ukr.net

Georgiyants Viktoria, Doctor of pharmaceutical sciences, Professor, head of the department, Pharmaceutical chemistry department, National University of Pharmacy, Pushkinska str., 53, Kharkiv, Ukraine, 61002

E-mail: vgeorg@ukr.net

\title{
УДК 615.322
}

DOI: $10.15587 / 2313-8416.2016 .61495$

\section{DEVELOPMENT OF METHODS FOR DETERMINATION OF PHENOLIC ACIDS AND FLAVONOIDS IN CAPSULES CONTAINING CORYLUS AVELLANA L. DRY EXTRACT}

\author{
(C) N. Blyznyuk, Yu. Prokopenko, V. Georgiyants
}

The questions of standardization and quality control of both herbs and herbal remedies remain relevant, because it is well-known that product quality standards are essential, whether consumer using herbs or drugs. The necessity of the standardization methods development for the initial herbal material and capsule dosage form for the further quality control under manufacturing conditions remains relevant.

Aim. The aim of our research was to develop simple, specific, accurate and reproducible methods for identification of flavonoids and phenolic acids in capsule dosage form containing Corylus avellana L. dry extract.

Methods. The samples of gelatine capsules containing Corylus avellana L. dry extract for oral administration were analyzed. The analysis was carried out using Camag HPTLC system.

The absorption spectroscopy determination of the sum of flavonoids was carried out using THERMO Scientific Evolution 605 Spectroscope in wavelength range of 300-600 $\mathrm{nm}$.

Results. As a result of HPTLC research rutine and quercitrine have been identified in capsule dosage form containing Corylus avellana L. dry extract. Among phenolic acids, neochlorogenic and chlorogenic acids have been identified.

Under the given conditions, the spectrum of the test solution had a maximum absorption at wavelength $406 \mathrm{~nm}$. The analysis of flavonoids total content in gelatine capsules containing Corylus avellana L. dry extract calculated as rutine has shown the content of 1,7\%.

Conclusion. Effective HPTLC and absorption spectroscopy methods for determination of flavonoids and phenolic acids in capsule dosage form containing Corylus avellana L. dry extract have been developed. It has been found that described methods are promising enough for standardization of capsules with Corylus avellana L. dry extract and may be suggested for the quality control of the dosage form under manufacturing conditions Keywords: capsules, Corylus avellana L., extract, HPTLC, absorption spectroscopy, phenolic acids, flavonoids

Питання стандартизації та контролю якості як рослин, так і лікарських засобів рослинного походження набуває актуальності, враховуючи той факт, щчо стандарти якості продукцї̈ є вкрай важливими, незалежно від того, чи вживає споживач лікарські рослини або лікарські засоби. Необхідність розробки методик стандартизаџї для вихідної рослинної сировини та капсульовано лікарської форми для подальшого контролю якості в умовах виробництва залишається актуальною.

Мета. Метою нашого дослідження була розробка простої, специфрічної, точної та відтворюваної методики ідентифікаиії флавоноїдів та фенольних кислот у капсульованій лікарській формі з сухим екстрактом Corylus avellana L.

Методи. Для дослідження використовували зразки желатинових капсул з сухим екстрактом Cоrylus avellana L. для орального застосування. Аналіз проводили з використанням системи Сатаg для ВЕТСХ. Визначення вмісту суми флавоноїдів методом абсорбиійної спектроскопії здійснювали за допомогою спектрометра THERMO Scientific Evolution 60S у діапазоні хвиль 300-600 нм.

Результати. В результаті ВЕТСХ аналізу у капсульованій лікарській формі з сухим екстрактом Согуlи avellana L. були ідентифіковані рутин та кверциитрин. Серед фенольних кислот були ідентифіковані неохлорогенова та хлорогенова кислоти.

В умовах проведення спектрофотометричного дослідження спектр випробовуваного розчину мав максимум поглинання за довжини хвилі 406 нм. Вміст суми флавоноїдів у желатинових капсулах з сухим екстрактом Corylus avellana L. у перерахунку на рутин становив 1,7 \%. 